\title{
F-type lectin from the sea bass (Dicentrarchus labrax): Purification, cDNA cloning, tissue expression and localization, and opsonic activity
}

\author{
G. Salerno ${ }^{\text {a }}$, M.G. Parisi ${ }^{\text {a }}$, D. Parrinello ${ }^{\text {a }}$, G. Benenati ${ }^{\text {a }}$, A. Vizzini ${ }^{a}$, M. Vazzana ${ }^{\text {a }}$, \\ G.R. Vasta ${ }^{\mathrm{b}}$, M. Cammarata ${ }^{\mathrm{a}, *}$ \\ ${ }^{a}$ Marine Immunobiology Laboratory, Department of Animal Biology, University of Palermo, Via Archirafi 18, Palermo, Italy \\ ${ }^{\mathrm{b}}$ Center of Marine Biotechnology, University of Maryland Biotechnology Institute, 701 E. Pratt Street, Baltimore MD, USA
}

\section{A R T I C L E I N F O}

Article history:

Received 8 June 2008

Received in revised form

16 December 2008

Accepted 3 January 2009

Available online 20 January 2009

Keywords:

F-type lectin

Dicentrarchus labrax

Teleost

Hemagglutinins

Opsonin

\begin{abstract}
A B S T R A C T
Recently described biochemical and structural aspects of fucose-binding lectins from the European eel (Anguilla anguilla) and striped bass (Morone saxatilis) led to the identification of a novel lectin family ("F-type" lectins) characterized by a unique sequence motif and a characteristic structural fold. The F-type fold is shared not only with other members of this lectin family, but also with apparently unrelated proteins ranging from prokaryotes to vertebrates. Here we describe the purification, biochemical and molecular properties, and the opsonic activity of an F-type lectin (DIFBL) isolated from sea bass (Dicentrarchus labrax) serum. DIFBL exhibits two tandemly arranged carbohydrate-recognition domains that display the F-type sequence motif. In situ hybridization and immunohistochemical analysis revealed that DIFBL is specifically expressed and localized in hepatocytes and intestinal cells. Exposure of formalin-killed Escherichia coli to DIFBL enhanced their phagocytosis by D. labrax peritoneal macrophages relative to the unexposed controls, suggesting that DIFBL may function as an opsonin in plasma and intestinal mucus.
\end{abstract}

(c) 2009 Elsevier Ltd. All rights reserved.

\section{Introduction}

Lectins are multivalent proteins that recognize and bind carbohydrate moieties through specific domains (CRDs) [1] and participate in various biological processes [2-5], including innate and adaptive immune responses [6,7]. Because most lectins may display CRDs in combination with other domains, they not only recognize carbohydrates on the surface of potential pathogens, but also mediate several effector functions including agglutination, immobilization, and opsonization of microbial pathogens, and complement pathway and phagocyte activation [8]. Based on the presence of conserved amino acid sequence motifs in their CRDs, structural fold, and calcium requirements, animal lectins have been classified into several families, such as C-, P-, I-, and L-type lectins, galectins, pentraxins, and others [6,9]. Recently, a novel lectin family (F-type; fucose-binding) characterized by a unique CRD sequence motif and structural fold has been identified both in prokaryotes and eukaryotes, including invertebrates and vertebrates [10-12]. The F-type CRD can be associated with pentraxin, C-type lectin, or "sushi" domains yielding complex chimaeric proteins [9].

\footnotetext{
* Corresponding author. Tel.: +39 091 6230109; fax: +39 0916230144

E-mail address: camat@unipa.it (M. Cammarata).
}

C-type, lectins, galectins, and rhamnose-binding lectins have been isolated from serum, skin mucus, and eggs from several fish species [13-16], and described as opsonic [6,17], or endowed with capacity to enhance respiratory burst and bactericidal activity of phagocytic cells [8,18-22].

F-type lectins have been identified and characterized in the serum from Anguilla japonica [13], Anguilla anguilla [12], Morone saxatilis [11], and Sparus aurata [23]. Although F-type lectins have been proposed to mediate role(s) as molecular recognition factors in innate immunity, the experimental evidence is fragmentary and the detailed mechanisms of their activity have not been elucidated [9]. Prior to the identification of the F-lectin family, a $34 \mathrm{kDa}$ fucosebinding $\mathrm{Ca}^{2+}$-independent serum lectin had been purified from the sea bass (Dicentrarchus labrax) and named DIFBL [24]. More recently, and based on partial N-terminal amino acid sequence, DIFBL and a similar lectin (SauFBP) from the gilt head sea bream (Sparus aurata) were both identified as members of the F-type lectin family [23].

In this study we analyzed in further detail the molecular properties and phylogenetic relationships of DIFBL. The lectin subunit contains two tandemly arrayed, distinct CRDs that exhibit the sequence motif typical of the F-type lectins. In situ hybridization and immunohistochemical analysis revealed that DIFBL is expressed and localizes in hepatocytes and intestinal mucocyte globet cells. Further, in an in vitro assay with peritoneal 
macrophages, DlFBL displayed opsonic activity for formalin-killed Escherichia coli, suggesting that it may function in recognition and opsonization of potential microbial pathogens in the blood stream and intestinal mucus.

\section{Material and methods}

\subsection{Chemicals, molecular biology reagents and bacterial strains}

Unless otherwise specified, chemicals and molecular biology reagents were from Sigma-Aldrich (USA). The E. coli (ATCC 25922) strain was from Chrysope Technologies (LA).

\subsection{Animals, collection of blood and tissue samples, and preparation of tissue extracts}

Sea bass ( $D$. labrax) ( $n=50$; approximately 250 g each) were provided by the Ittica Trappeto fish-farm (Trappeto, Palermo, Italy). Animals were anaesthetized in seawater containing 0.02\% 3-aminobenzoic acid ethyl ester (MS-222 Sigma), and bled by heart puncture. The blood was allowed to clot at room temperature for $1 \mathrm{~h}$, the serum separated by centrifugation at $800 \times \mathrm{g}\left(10 \mathrm{~min}, 4^{\circ} \mathrm{C}\right)$, aliquoted, and stored at $-20^{\circ} \mathrm{C}$ until use.

Liver and intestine were excised from freshly killed fish and immediately frozen by immersion in liquid nitrogen. Frozen samples were ground into powder under liquid nitrogen, suspended in TBS ( $50 \mathrm{mM}$ Tris- $\mathrm{HCl}, 0.15 \mathrm{M} \mathrm{NaCl}, \mathrm{pH} 7.4$ ), centrifuged at $15,000 \times \mathrm{g}$ and the supernatant stored at $-80^{\circ} \mathrm{C}$.

\subsection{Purification of sea bass serum F-type lectin (DlFBL)}

The DIFBL was isolated by an optimized two-step chromatography procedure. The first step consisted of a Sepharose CL6B affinity cromathography column eluted with $0.2 \mathrm{M}$ galactose, as previously reported [24]. As monitored by absorbance at $280 \mathrm{~nm}$, the elution profile yielded two peaks, of which the second displayed the highest hemagglutinating activity (titre: 256-512). In the second separation step, DIFBL was purified by loading the pooled active fractions from the second peak on a fucose-agarose affinity chromatography following the method reported by Honda et al. [13]. Briefly, the fractions of the Sepharose CL6B peak $2(20 \mathrm{ml}$; about $1-2 \mathrm{mg} \mathrm{ml}^{-1}$ protein content) were pooled, dialyzed against TBS, centrifuged at $10,000 \times g$ for $30 \mathrm{~min}$, and passed through a $5 \mathrm{ml}$ L-fucose-agarose column (Pierce). The column was washed with $1.0 \mathrm{M} \mathrm{NaCl}$, followed by TBS (10 volumes) at a $0.2 \mathrm{ml} / \mathrm{min}$ flow rate. The elution of DIFBL was carried out with $20 \mathrm{ml}$ of $50 \mathrm{mM}$-fucose in TBS at the same flow rate, monitored by absorbance at $280 \mathrm{~nm}$, and with $2 \mathrm{ml}$ fractions collected. These were tested for hemagglutinating activity towards rabbit erythrocytes, and those that exhibited the highest activity were pooled and analyzed by electrophoresis

\subsection{Hemagglutination assay}

Rabbit and sheep erythrocytes (RBC; supplied by Istituto Zooprofilattico della Sicilia) were washed three times with PBS, centrifuged at $500 \times \mathrm{g}$ for $10 \mathrm{~min}$ at $4{ }^{\circ} \mathrm{C}$ and suspended at $1 \%$ in TBS containing $0.1 \%(\mathrm{w} / \mathrm{v})$ pig gelatin. A volume $(25 \mu \mathrm{l})$ of sea bass $\operatorname{serum}(1: 10)$ or $25 \mu \mathrm{l}$ of the purified DIFBL preparation $(250 \mu \mathrm{g} / \mathrm{ml})$ dialyzed in TBS were serially (2-fold) diluted with TBS-gelatin in 96-well round-bottom microtitre plates (Nunc, Denmark), and mixed with an equal volume of RBC suspension. The hemagglutinating titre (HT) was measured after $1 \mathrm{~h}$ incubation at $37^{\circ} \mathrm{C}$, and expressed as the reciprocal of the highest dilution showing clear agglutination.

\subsection{Protein content estimation}

Protein content was estimated according to the method of Bradford [25], using bovine serum albumin (BSA) as a standard.

\subsection{Polyacrylamide gel electrophoresis}

SDS-PAGE (10\%) was carried out following the method of Laemmli [26], under reducing conditions (5\% mercaptoethanol). To evaluate the molecular size, gels were calibrated with low range standard proteins (Bio-Rad, Richmond, CA). Proteins were stained with Coomassie brillant Blue R-250.

\subsection{Preparation of anti-DIFBL antisera}

As previously described [24], bands identified in the SDS-PAGE gels as the purified DIFBL were excised and pooled, suspended in distilled water, and passed repeatedly through a syringe. AntiDIFBL antibodies were raised in rabbits by Medprobe (Norway), with a coarse suspension of the gel pool containing $\operatorname{DIFBL}(50 \mu \mathrm{g})$ as the antigen. To control for antibody specificity, the antiserum was absorbed with the purified lectin. Briefly, $500 \mu \mathrm{l}$ of anti-DIFBL antiserum were mixed with $100 \mu$ l of the affinity chromatography Fraction II ( $50 \mu \mathrm{g}$ protein content), incubated overnight at $4{ }^{\circ} \mathrm{C}$, and centrifuged at $27.000 \times g$ for $1 \mathrm{~h}$ at $4^{\circ} \mathrm{C}$. Specificity of the anti-DIFBL antibodies was validated by comparing the activity of the diluted (5:1 in PBS: $\mathrm{Na}_{2} \mathrm{HPO}_{4} 1 \mathrm{M}, \mathrm{NaH}_{2} \mathrm{PO}_{4} 1 \mathrm{M}, \mathrm{NaCl} 1,5 \mathrm{M}, \mathrm{pH} 7.4$ ) antiserum with the adsorbed one.

\subsection{Western blot analysis}

SDS-PAGE gels were soaked in transfer buffer $(20 \mathrm{mM}$ Tris, $192 \mathrm{mM}$ glycine, $10 \%$ methanol, $\mathrm{pH} 8.8$ ) for $10 \mathrm{~min}$ and proteins transferred for $75 \mathrm{~min}$ at $0.8 \mathrm{~mA} / \mathrm{cm}^{2}$ to nitrocellulose sheet in a semi dry blotting bath (Bio-Rad, USA). The filter was soaked in blocking buffer (PBS containing 3\% BSA and $1 \%$ Tween 20) for $1.5 \mathrm{~h}$. After washing with PBS-T the nitrocellulose sheet was incubated with anti-DlFBL antiserum (1:800 in PBS) for $1 \mathrm{~h}$, then washed 4 times with blocking buffer, and incubated for $1 \mathrm{~h}$ with alkaline phosphatase-conjugated anti-rabbit sheep IgG (Sigma; 1:15,000 in blocking buffer). After washing with PBS (4 times for $15 \mathrm{~min}$ ), the filter was treated with $3 \mathrm{ml}$ of 5-bromo-4-chloro-3-indolyl phosphate/nitro blue tetrazolium (BCIP/NBT) liquid substrate system.

\subsection{Isolation of total RNA from liver, PCR amplification, and $C D N A$ cloning}

Total RNA was isolated from liver by using an RNAqueousTMMidi kit purification system (Ambion), and reverse-transcribed with the Ready to Go T-primed first-strand kit using random primers (Amersham-Pharmacia Biotech). Amplification was performed by using $1 \mathrm{mM}$ of the following degenerate primers, designed on the basis of sequences: P1.DFBP1.F (5'-dCAAAGCTTTAYAACTAYAARAACGTNGC-3'); P2. DFBP3.R (5'dTCGAATTCGTNACGATRTANGGCTC-3'). PCR amplification was carried out in a MJ Research DNA PTC-100 thermal cycler as follows: after a denaturating step at $94{ }^{\circ} \mathrm{C}$ for $3 \mathrm{~min}$, the primers were annealed at $37^{\circ} \mathrm{C}$ for $30 \mathrm{~s}$, then 35 amplification cycles $\left(94^{\circ} \mathrm{C}\right.$ for $30 \mathrm{~s}, 50{ }^{\circ} \mathrm{C}$ for $30 \mathrm{~s}$, and $72{ }^{\circ} \mathrm{C}$ for $1 \mathrm{~min}$ ) and a final elongation at $72{ }^{\circ} \mathrm{C}$ for $10 \mathrm{~min}$ were carried out. A single band of $136 \mathrm{bp}$ in size was visible in agarose-gel electrophoresis (not shown). This product was ligated into the pCR 4-TOPO (TA cloning Kit, Invitrogen) according to the manufacturer's instructions. Plasmid DNA was isolated from recombinant bacterial clones using NucleoSpin extraction kit (Macherey-Nagel Sarl, Hoerdt, France), and 
sequenced at CRIBI (Univ of Padova-Italy) as a service. The cDNA sequences were completed by $5^{\prime}$ - and $3^{\prime}$ RACE using the Marathon RACE kit (Clontech), with the internal specific primers described above.

\subsection{Expression analysis of DIFBL in several tissues}

To determine whether the F-lectin was expressed in kidney, spleen, ovary, gills, intestine and heart tissues, total RNA was isolated by using a RNAqueous ${ }^{\mathrm{TM}}$-Midi Kit purification system (Ambion) and reverse-transcribed by the Cloned AMV First-Strand cDNA Synthesis Kit (Invitrogen). The following primers were designed by using the liver cDNA sequence: upper primer, $5^{\prime} \mathrm{d}$ -TCTGTGAAGTGGAGGTTTAT-3'; lower primer, 5'd-AGGGTCAGG TACTCTTCTTT-3'. PCR amplification was carried out as follows: $94{ }^{\circ} \mathrm{C} 1 \mathrm{~min}, 52{ }^{\circ} \mathrm{C} 1 \mathrm{~min}, 72{ }^{\circ} \mathrm{C} 1 \mathrm{~min}$ for 30 cycles. A single band of $390 \mathrm{bp}$ was visible in agarose-gel electrophoresis. The amplicon was purified and sequenced at CRIBI (Biotechnology Center of the University of Padua, Italy, http://bmr.cribi.unipd.it, ABI PRISM-DNA sequencer, Applied Biosystems). A similarity search was performed using the FASTA program (http://www.ebi.ac.uk/Tools/fasta/). The signal peptide has been determined by signalP algorihtm http:// www.cbs.dtu.dk/services/SignalP/. Proteins from the above mentioned tissues were prepared by adding liquid nitrogen to the dissected organs in a mortar, the frozen tissues ground to a fine powder with a pestle for $10-15 \mathrm{sec}$, and $1 \mathrm{ml}$ of RIPA buffer (25 mM PBS -Tween 20 buffer pH 7.6, 150 mM NaCl, 1\% NP-40, 1\% sodium deoxycholate, $0.1 \%$ SDS) was added. The sample was centrifuged at $27,000 \times \mathrm{g}$ for $30 \mathrm{~min}$ at $4{ }^{\circ} \mathrm{C}$, the resulting pellet was removed, and the supernatant used as crude extract or frozen at $-80^{\circ} \mathrm{C}$

\subsection{Phylogenetic analysis}

The deduced amino acid sequences were submitted to multiple alignments using the Clustal W v. 1.81 program [27]. Alignment of protein sequences was done using CLUSTAL X v.1.83 [28] (ftp://ftpigbmc.u-strasbg.fr/pub/) and similarity shaded with GeneDoc v.2.6.002 (www.psc.edu/biomed/genedoc/) and Bioedit version 5.0.9. A phylogenetic tree was constructed by the NeighbourJoining method (NJ), considering 1000 bootstrap hits.

Calculations of theoretical protein characteristics from the deduced peptide sequence were performed with ProtParam (www. expasy.ch). The putative tertiary structure of each CRD from DIFBL was modeled using the crystallographic structure of the A. anguilla F-type lectin as a template [12]. The polypeptide sequence of each CRD was aligned to the $A$. anguilla F-type lectin template structure (Protein Data Bank accession code 1K12) using Cn3D 4.1 produced by NCBI.

\subsection{In situ hybridization}

In situ hybridization was performed on tissue sections $(7 \mu \mathrm{m})$ according to Alonso et al. [29]. Antisense (AS) and sense (S) probes were synthesized based on the DIFBL cDNA clone. Digoxigeninlabeling was performed using the digoxigenin-UTP in vitro transcription kit (Roche Diagnostics, Meylan, France) according to the manufacturer's instructions. The sections were washed twice in PBS-T ( $1 \mathrm{M} \mathrm{Na}_{2} \mathrm{HPO}_{4}, 1 \mathrm{M} \mathrm{NaH}_{2} \mathrm{PO}_{4}, 1.5 \mathrm{M} \mathrm{NaCl}, \mathrm{pH} 7.4$ 0.1\% Tween 20), permeabilized with $1 \mu \mathrm{l} \mathrm{ml}^{-1}$ proteinase $\mathrm{K}$ (Sigma-Aldrich) in PBS-T, and the reaction blocked by $2 \mathrm{mg} \mathrm{ml}^{-1}$ glycine in PBS-T. After washing with PBS-T, the sections were post-fixed for $30 \mathrm{~min}$ with $4 \%$ formaldehyde in PBS-T, treated with hybridization solution (50\% formamide, $50 \mu \mathrm{g} \mathrm{ml}^{-1}$ heparin, 500 yeast tRNA, $0.1 \%$ Tween 20 and $5 \mathrm{x}$ sodium chloride/sodium citrate solution (SSC): $0,15 \mathrm{M} \mathrm{NaCl} /$
$0.05 \mathrm{M}$ sodium citrate, $\mathrm{pH} 7$ ) at $42{ }^{\circ} \mathrm{C}$ for $1 \mathrm{~h}$, followed by $15 \% \mathrm{AS}$ probe in hybridization solution at $42{ }^{\circ} \mathrm{C}$ overnight. After washing with PBS-T at $42{ }^{\circ} \mathrm{C}(10 \mathrm{~min})$ and then with $0.3 \%$ SSC $20 \mathrm{x}$ containing $1 \%$ Tween 20 , the sections were incubated for $30 \mathrm{~min}$ at $20^{\circ} \mathrm{C}$ with $2 \%$ horse serum in PBS-T, and then treated for $1 \mathrm{~h}$ at $20^{\circ} \mathrm{C}$ with antidigoxigenin-Fab-Ab (Roche Diagnostics, Meylan, France) diluted 1:100 in the horse serum-PBS-T solution. Finally, the sections were washed twice in PBS-T and incubated with BCIP/NBT for $2 \mathrm{~h}$ in the dark. Controls consisted of tissue sections processed similarly, using the corresponding sense RNA $\left(1 \mu \mathrm{g} \mathrm{ml}^{-1}\right)$. Three individual fishes were examined for both experimental and control sections.

\subsection{Immunohistochemical and immunocytochemical methods}

Liver and intestine samples (approximately $300 \mathrm{mg}$ ) were fixed in Bouin's for $24 \mathrm{~h}$, rinsed in ethanol $75 \%$ and embedded in paraffin. Serial sections ( $5 \mu \mathrm{m}$ ) were treated for 30 min with PBS containing $0.2 \%$ Triton X-100 and $0.1 \%$ Tween 20 (PBS-T). To prevent nonspecific antibody binding, the sections were incubated with $3 \%$ BSA in PBS for $1.5 \mathrm{~h}$ at room temperature. After two washings in PBS-T, the sections were incubated overnight with anti-DIFBL antibodies (1:800 in PBS-T containing 0,1\% BSA), and, after washing, the sections incubated for $1.5 \mathrm{~h}$ at room temperature with sheep antirabbit IgG alkaline phosphatase conjugate as the secondary antibody (1:15,000 in PBS-T 0,1\% BSA). After washing in PBS-T the sections were treated with the substrate mixture ( $3 \mathrm{ml}$ of 5 -bromo4-chloro-3-indolyl phosphate/nitro blue tetrazolium, BCIP/NBT) and the reaction blocked in distilled water. To validate the antibody specificity, the following controls were performed: (1) The antiDIFBL antiserum was replaced with pre-immune rabbit serum; (2) the primary (anti-DIFBL) antibodies were replaced with PBS; 3. anti-DIFBL antiserum was replaced with the absorbed anti-DIFBL antiserum.

Histological sections were stained with Mallory stain $(0.5 \%$ of aniline blue; $2 \%$ orange $\mathrm{G}$; $2 \%$ oxalic acid in distilled water) for $30 \mathrm{~min}$ [30], or with Gomori trichromic stain [Chromotrope 2R $(0.6 \mathrm{~g})$, Fast green FCF $(0.3 \mathrm{~g})$, phosphotungstic acid $(0.8 \mathrm{~g})$, glacial acetic acid (1 ml), $100 \mathrm{ml} \mathrm{DW]} \mathrm{for} 30 \mathrm{~min}$ [31].

\subsection{Bacterial suspensions}

Bacteria were grown to log phase in tryptic soy broth (TSB) containing $3 \% \mathrm{NaCl}$ at $25^{\circ} \mathrm{C}$, with continuous shaking (120 rpm) in a Gallenkamp incubator. Cell numbers were estimated by absorbance at $600 \mathrm{~nm}$. The relationship between absorbance and cell number had previously been determined by plate count, and cultures were diluted to a final $10 \%$ bacterial stock suspension. Bacteria were fixed by adding formaldehyde to the bacterial stock suspension to a $2 \%$ final concentration, and the mixture shaken (120 rpm) overnight at $21^{\circ} \mathrm{C}$. After centrifugation at $6000 \times \mathrm{g}$ for $15 \min \left(4^{\circ} \mathrm{C}\right)$, the formalin-killed bacteria were washed three times with sterile PBS, suspended in PBS containing $0.1 \%(\mathrm{w} / \mathrm{v})$ gelatin to obtain $1 \times 10^{9}$ cells $\mathrm{ml}^{-1}$, and stored at $4{ }^{\circ} \mathrm{C}$ until use.

For the phagocytosis assay, the formalin-killed bacteria were washed three times with sterile PBS, suspended $1 \times 10^{9} \mathrm{ml}^{-1}$ in carbonate buffer $\left(0.1 \mathrm{M} \mathrm{Na}_{2} \mathrm{CO}_{3}, 0.1 \mathrm{M} \mathrm{NaHCO}\right.$, $\left.\mathrm{pH} 9.5\right)$ containing $0.1 \mathrm{mg} \mathrm{ml}^{-1}$ FITC and incubated $30 \mathrm{~min}$ at $37^{\circ} \mathrm{C}$ with gentle shaking. FITC-treated formalin-killed bacteria were washed three times in $\mathrm{NaCl} 0.9 \%$ and twice in PBS containing $2 \mathrm{mM} \mathrm{CaCl}_{2}$, and suspended $\left(1 \times 10^{8} \mathrm{ml}^{-1}\right)$ in PBS-Ca.

\subsection{Collection of peritoneal macrophages}

Peritoneal cavity cells (PCC) were harvested by injecting $10 \mathrm{ml} \mathrm{L}-$ 15 medium [L-15 medium (Leibovitz) without L-glutamine, liquid, 
sterile-filtered, cell culture tested; Sigma] containing 100 units $\mathrm{ml}^{-1}$ penicillin/streptomycin and 10 units $\mathrm{ml}^{-1}$ heparin into the peritoneal cavity. The body cavity was massaged for $10 \mathrm{~min}$, and the medium containing the peritoneal cells was withdrawn with a sterile syringe and centrifuged at $500 \times g$ for $10 \mathrm{~min}$. The cell

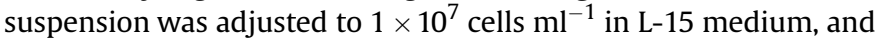
cell viability was evaluated by the trypan blue exclusion test.

\subsection{Phagocytosis assay}

FITC-treated formalin-killed bacteria $\left(1 \times 10^{8} \mathrm{ml}^{-1}\right)$ were mixed in a microtube with purified F-lectin $\left(5,10,25 \mu \mathrm{g} \mathrm{ml}^{-1}\right)$ in $\mathrm{PBS} \mathrm{Ca}^{2+}$, incubated at $18{ }^{\circ} \mathrm{C}$ for $60 \mathrm{~min}$, and washed twice with the same buffer. In the controls the purified lectin was replaced with PBS $\mathrm{Ca}^{2+}$. The opsonized bacteria $(100 \mu \mathrm{l})$ were incubated with an equal volume of PCCs $\left(1 \times 10^{7} \mathrm{ml}^{-1}\right)$ for $30 \mathrm{~min}$ at $18^{\circ} \mathrm{C}$. Fluorescence of the non-phagocytosed bacteria, was quenched by adding trypan blue $\left(2 \mathrm{mg} \mathrm{ml}^{-1}\right.$ ) in $0.02 \mathrm{M}$ citrate buffer $\mathrm{pH} 4.4$, containing $0.15 \mathrm{M}$ $\mathrm{NaCl}$ and $2 \mathrm{mg} \mathrm{ml}^{-1}$ crystal violet in PBS [32]. The phagocytosed fluorescent bacteria were observed under a UV light microscope equipped with Nomarsky differential interference contrast optic (Diaplan, Leica, Wetzlar, Germany). The phagocytic rate (PR) was determined as the percent of cells showing internalized bacteria, and the phagocytic index (PI) as the average of ingested bacteria relative to the total phagocyte number.

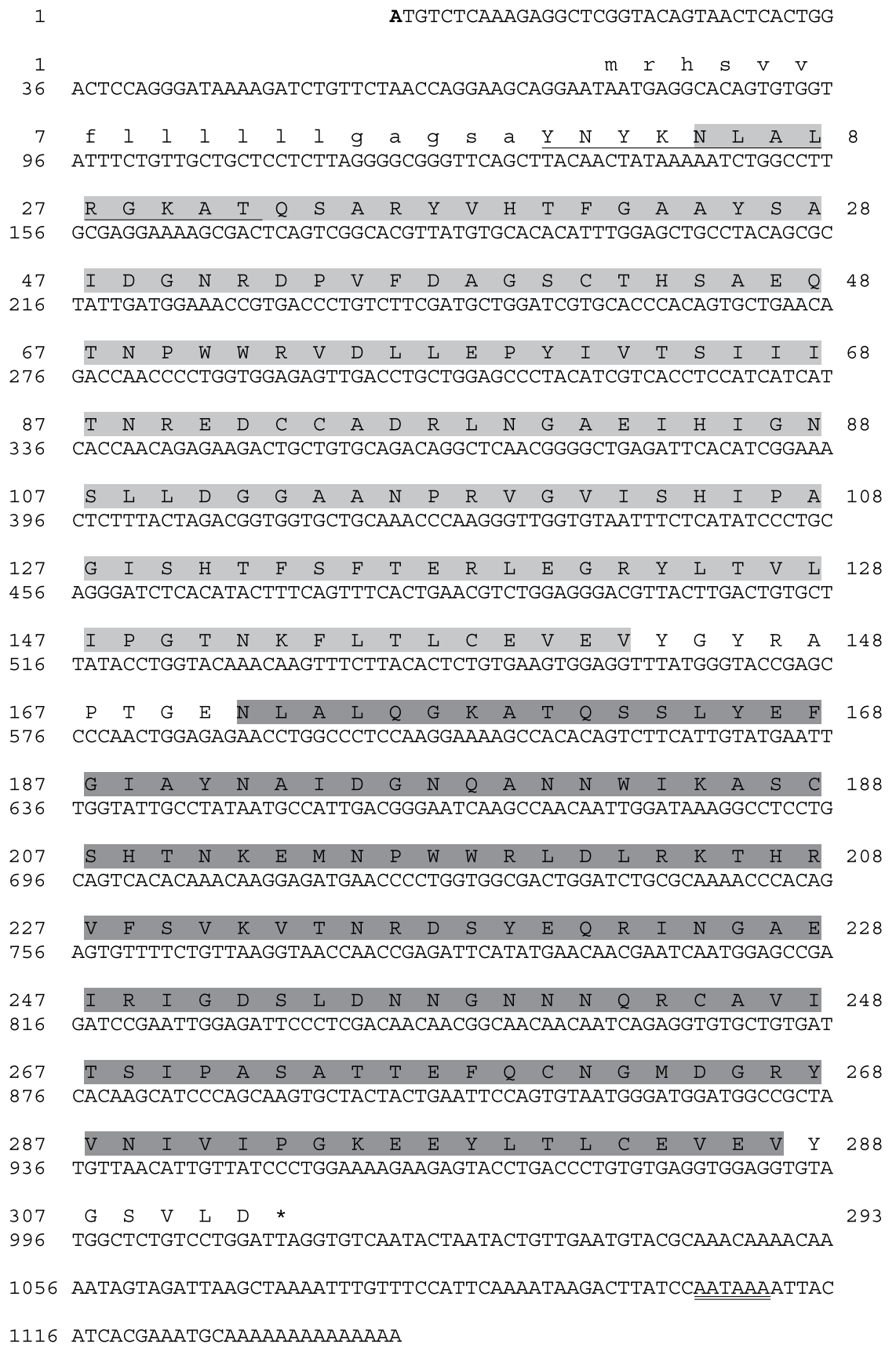

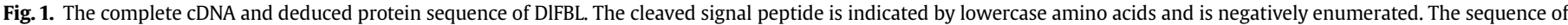

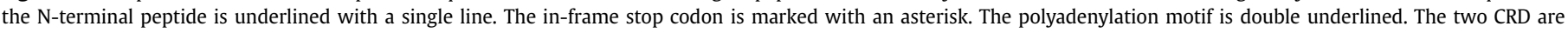
highlighted in grey (Accession number EU877448). 


\section{Results}

\subsection{DIFBL cDNAs cloning and sequence analysis}

By using degenerate P1, P2 primers designed on the basis of $M$. saxatilis sequences a $136 \mathrm{bp}$ long amplicon was obtained. To elucidate the sequence of the entire transcript $3^{\prime}$ and $5^{\prime}$ RACE-PCR using the specific primers P3 and P4 designed from the initial 136 bp amplicon was carried out. The 1142 bp cDNA product presented the complete cDNA sequence with an open reading frame encoding 312 amino acids (Fig. 1). Nucleotide sequence analysis showed that a 77-nucleotide $5^{\prime}$-UTR preceded the putative translation start site, and a 93-nucleotide 3'-UTR spanned from the stop codon up to the polyadenylation site resulting in a 1128-nucleotide transcript excluding the poly $(\mathrm{A})$ tail. The deduced protein sequence (Fig. 1) was 293 residues long. The cleavage site of the 18-residue signal sequence at the $\mathrm{N}$-terminal was predicted by the SignalP algorithm to reside between $\mathrm{Ala}^{18}$ and $\mathrm{Tyr}^{19}$. Therefore, the calculated molecular mass of the DIFBL is $34.4 \mathrm{kDa}$ (ProtParam; www. expasy.ch), with a theoretical isoelectric point of 5.84 .

A comparative sequence analysis (Fig. 2) revealed the presence of two CRDs spanning from $\mathrm{Asn}^{5}$ to $\mathrm{Gly}^{143}$ (N-CRD) and from $\mathrm{Asn}^{153}$ to $\mathrm{Gly}^{287}$ (C-CRD) connected by a nine amino acid linker peptide.

\subsection{Phylogenetic analysis and CRD comparison}

BLAST analysis revealed that the DIFBL deduced amino acid sequence presents close homologies with vertebrate F-lectins depending on their CRD organization. In the phylogenetic tree (Fig. 2), DIFBL clustered with the other binary (two CRDs) teleost FBPs. A second cluster includes F-lectins from Anguilla species and Tetraodon nigroviridis, which are characterized by a single CRD, whereas F-lectins containing more than two CRDs form a third cluster. Finally, a cluster of heterogeneous proteins, containing significant sequence similarity to F-type CRDs from bacteria, insects, sea urchin, and Xenopus was identified.

Detailed phylogenetic analysis of the CRD in binary fish F-lectins (Fig. 3) showed highly conserved sequences in their N-CRDs or C-CRDs, being the N-CRDs closer to the Anguilla CRD cluster. Conserved Cys form two disulphide bounds (Cys ${ }^{42}-\mathrm{Cys}^{139}$ and $\mathrm{Cys}^{97}$-Cys ${ }^{113}$ ), whereas an additional bond $\left(\mathrm{Cys}^{74}-\mathrm{Cys}^{75}\right)$ is present in the $A$. anguilla F-type lectin. Conserved amino acids involved in sugar binding ( $\mathrm{His}^{44}, \mathrm{Arg}^{70}, \mathrm{Arg}^{77}$ ) were present in both N-CRDs and C-CRDs (Fig. 4).

\subsection{SDS-PAGE analysis of the DIFBL purified fractions}

Fig. 5 shows a typical fucose-agarose affinity chromatography purification profile of $20 \mathrm{ml}$ of pooled fractions from Sepharose chromatography (peak 2, 3-5 $\mathrm{mg} \mathrm{ml}^{-1}$ protein; 256-512 HA). The purified agglutinating fraction (peak 2, 30-32 fractions pooled) contained $131 \pm 44 \mu \mathrm{g}$ DIFBL ml ${ }^{-1}(n=4)$ with a $512-1024$ HT. The specific activity (HT $\times$ volume/protein content: 11,035 for the DIFBL pool; 1076 for Sepharose CL6B active fraction; 64 for whole serum) of the DIFBL pool was 160 to 180 -fold higher than that of whole serum, and SDS-PAGE under reducing conditions revealed a single 34 kDa component (DIFBL, Fig. 6, lane 1). The fractions (6-12) from peak 1 collected before the column was eluted with L-fucose, showed no hemagglutinating activity. SDS-PAGE under reducing conditions of peak 2 from the first Sepharose chromatography step revealed an intense $34 \mathrm{kDa}$ band and a minor $70 \mathrm{kDa}$ component. Both protein bands were eluted from the gel. The N-terminal sequence of the $70 \mathrm{kDa}$ (APAEKVK) protein was $100 \%$ identical to the putative $\mathrm{N}$-terminal sequence of transferrin from the teleost Acanthopagrus schlegelii.

When the active fractions from the first and second separation steps were analyzed by SDS-PAGE under non-reducing conditions, the mobility of the $34 \mathrm{kDa}$ band increased to an equivalent mass of $30 \mathrm{kDa}$ (Fig. 6, lane 2), suggesting the presence of disulfide bonds in DIFBL.

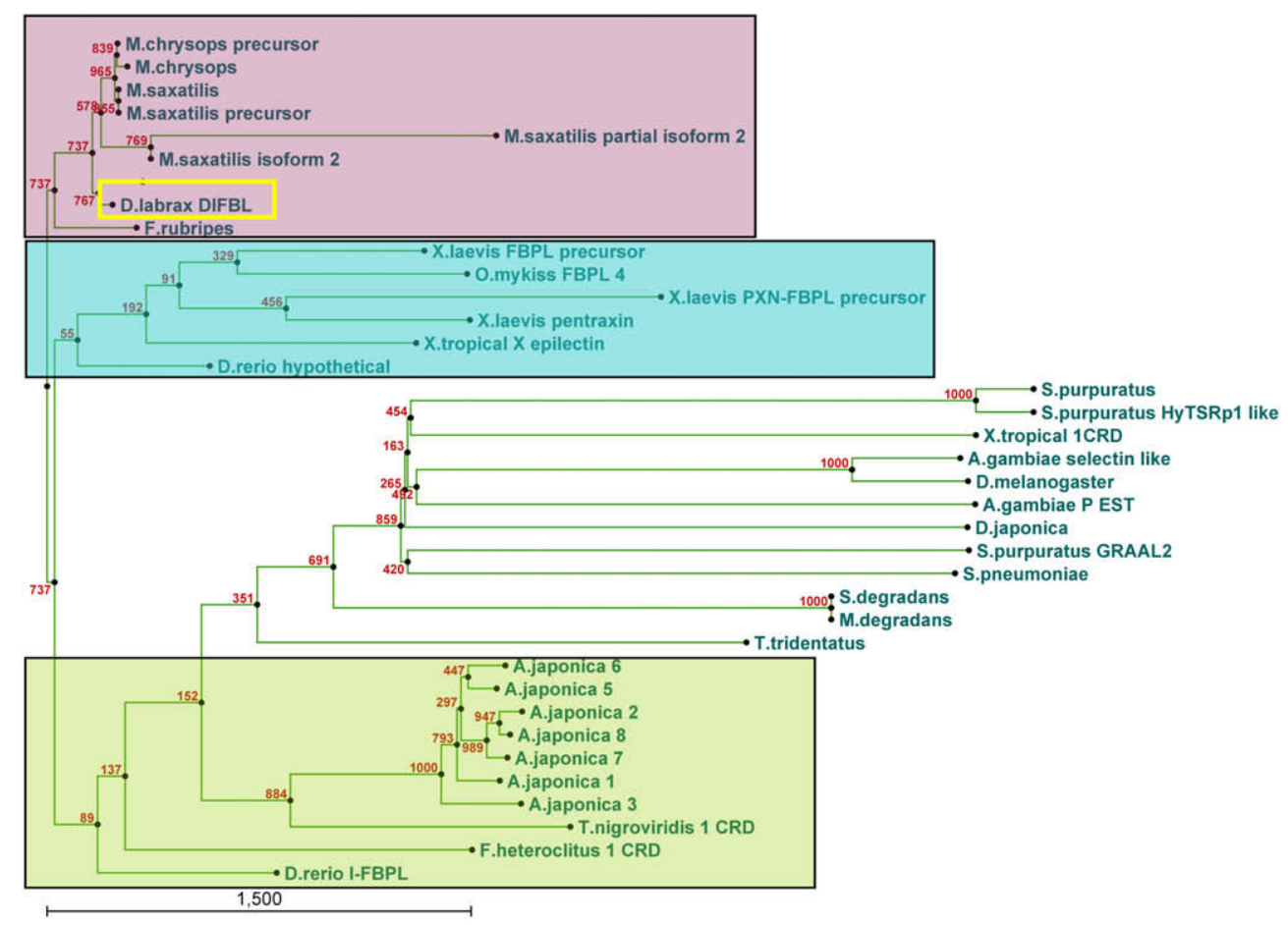

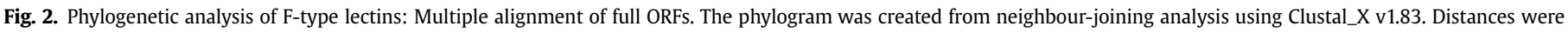
corrected for multiple substitutions and gap positions were excluded. Bootstrap values are percentages from 1000 iterations. Scale bar measures substitutions per site. 


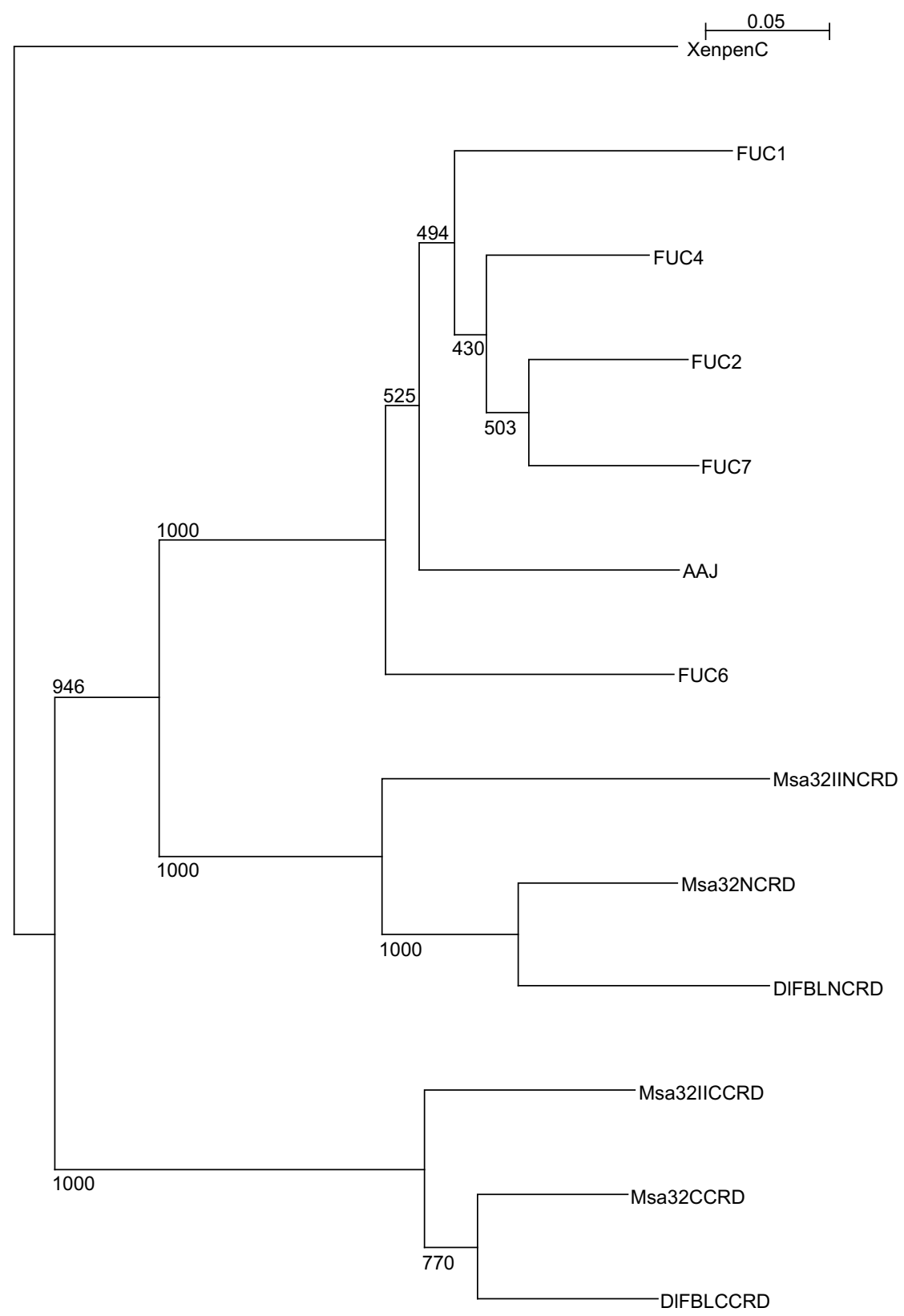

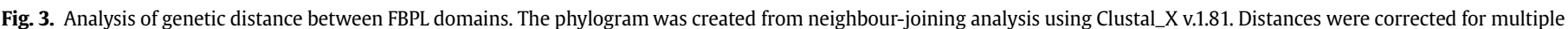

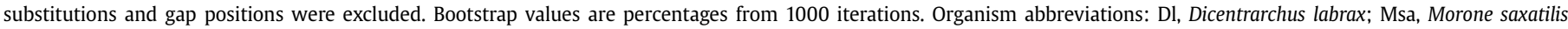
(striped bass); AAJ, Anguilla japonica (Japanese eel); Xenpen, Xenopus tropicalis (diploid clawed frog); FUC, A. anguilla fucolectin 1-7.

\subsection{Immunoblotting of serum and tissue homogenate supernatants}

Western blot analysis (Fig. 6) of the isolated fraction showed that anti-DIFBL antibodies reacted equally well with both the $34 \mathrm{kDa}$ band (Fig. 6, lane 3 ) observed under reducing conditions, and the $30 \mathrm{kDa}$ band found under non-reducing conditions (Fig. 6, lane 4).

The $34 \mathrm{kDa}$ DlFBL was identified in protein extract from liver, intestine, head kidney, spleen, ovary, gill and heart. However, differences in the band density indicated that the protein was mainly contained in the liver and intestine, whereas a thin band was visible in the head kidney, spleen, ovary, gill, and heart preparations (Fig. 7b). The specificity of the anti-DIFBL antiserum was validated by testing the pre-immune rabbit serum and the antiserum absorbed with purified DIFBL. No bands were observed with either antisera (Fig. 6, lanes 7 and 8, respectively). In addition, no bands were observed in the control where the primary (anti-DlFBL) antibody was omitted.

\subsection{Immunohistochemical analysis}

Anti-DIFBL antibodies identified DIFBL epitopes in liver parenchymal cells (Fig. 8a), and intestinal mucocyte globet cells (Fig. 8d arrows) interposed between the absorbent cells of the intestinal columnar epithelium. The specificity of the antibody binding was confirmed by replacing the primary antibody with pre-immune rabbit serum or omitting the primary antibody (Fig. $8 \mathrm{~b}, \mathrm{e}$ ), and by treating sections with the absorbed antiserum (Not shown). In either control no stained cells were observed (Fig. 8 b, e). No antibody binding was observed in head kidney, spleen, heart, gill and ovary histological sections. 


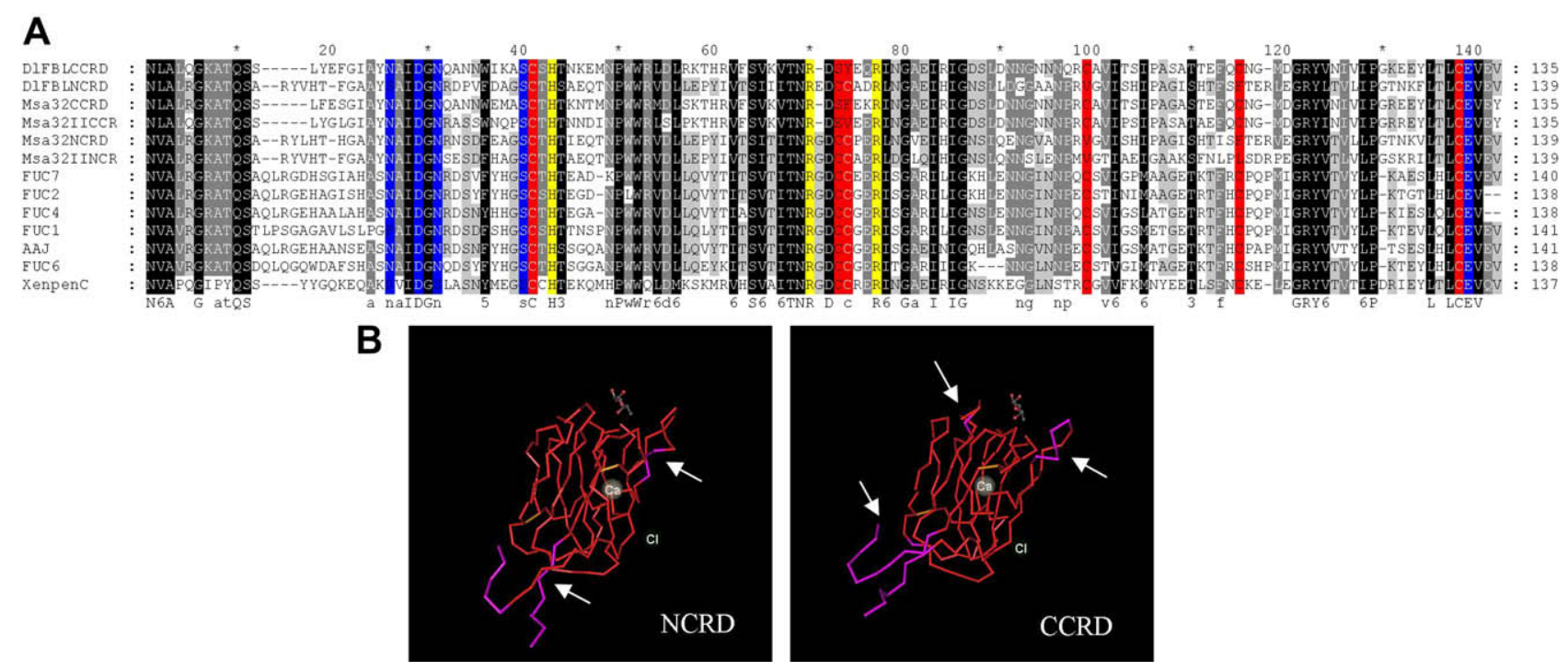

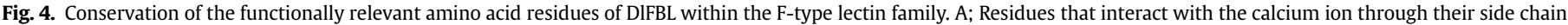

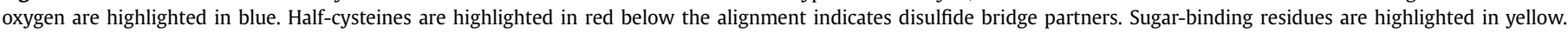

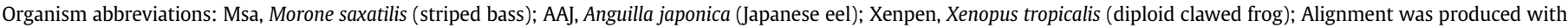

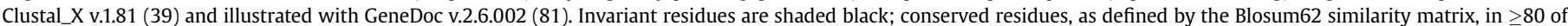

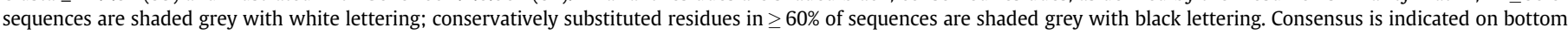

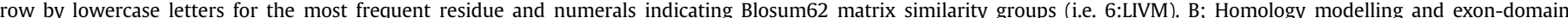

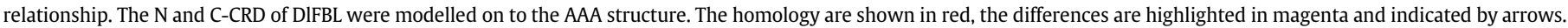

\subsection{DIFBL mRNA expression and in situ hybridization}

RT-PCR analyses by using a specific primer pair identified the presence of DIFBL transcripts in several organs and tissues. Both liver and intestine expressed a $390 \mathrm{bp}$ mRNA (Fig. 7a). A lower level of the transcript was expressed in the head kidney, spleen, ovary, whereas it was absent in gills and heart. The 390 bp bands purified from these organs, revealed a sequence identical to $34 \mathrm{kDa} N$ terminal sequence was in accordance with the amino acid sequence deduced from the DIFBL cDNA (data not shown).

In situ hybridization experiments were limited to liver and intestine, where the transcript was abundantly expressed (Fig. 9). The antisense riboprobe was found in the nucleus of liver parenchymal cells (Fig. 9a), intestinal columnar ephitelium cells and mucocyte globet cells in the intestine (Fig. 9c). No signal was observed when the sense probe was used (Fig. 9b, d).

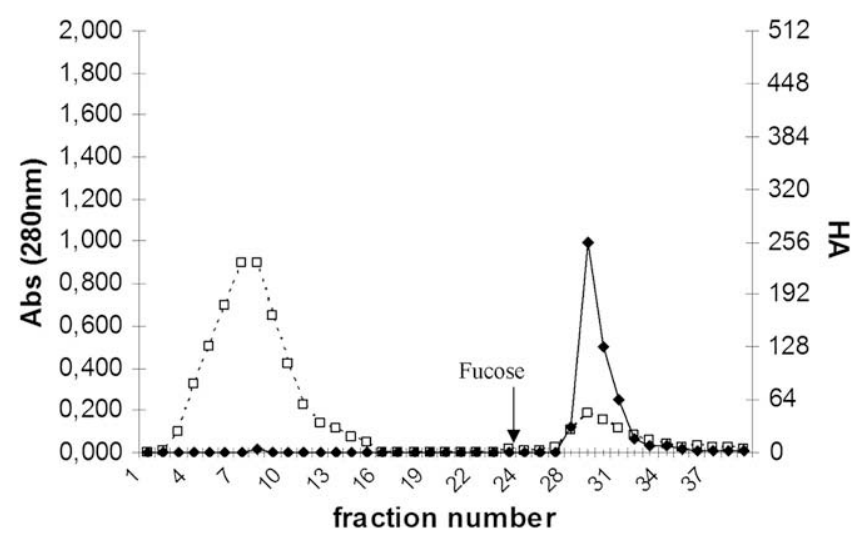

Fig. 5. Affinity chromatography of $D$. labrax pooled active fractions from a Sepharose CL6B on a fucose-agarose column absorbance at $280 \mathrm{~nm}(\square)$; Hemagglutinating activity $(\bullet)$.

\subsection{Effect of DlFBL on phagocytic activity of peritoneal macrophages}

The phagocytic activity of peritoneal macrophages increased significantly after bacteria were opsonized with the isolated DIFBL $(16.9 \pm 6.9 \%$; 300 cells were counted in three distinct assays) (Fig. 10a), while the phagocytic index values were doubled (from $1.8 \pm 0.9$ up to $3.5 \pm 2.1 p<0.005$ ). The opsonic effect of DIFBL was carbohydrate-specific as shown by opsonization-inhibition experiments. Galactose or glucose added in the phagocytosis mixture (25 mM final concentration) did not affect the opsonic effect of DIFBL, whereas the presence of $25 \mathrm{mM}$ fucose reduced the phagocytosis activity $(7.7 \pm 1.8 \%$ phagocytes $)$ to levels similar to those for the non-opsonized bacteria of the control (Fig. 10a).

The opsonizing effect of DIFBL showed a dose-response profile, with increasing phagocytic activity levels when bacteria were pretreated with $5(p<0.001)$ and $10 \mu \mathrm{g} \mathrm{ml}^{-1}(p<0.01)$ DlFBL, and showing a moderate decrease relative to the latter at $25 \mu \mathrm{g} \mathrm{ml}^{-1}$ $(p<0.001)$ DlFBL (Fig. 10b). Internalization of the FITC-labelled bacteria by the peritoneal macrophages could be visualized by fluorescence microscopy (Fig. 10c, d).

\section{Discussion}

Lectins play important roles in the immune response of invertebrates and vertebrates either by recognizing exposed glycans of potential pathogens or by their immunoregulatory roles through the binding to carbohydrates on the surfaces of immunocompetent cells [2-4,33,34]. Despite the relatively weak binding affinities of the CRD for the carbohydrate ligands, high avidity is achieved through the cooperative binding interactions of the multiple CRDs displayed that result from (a) the bouquet- or cruciform-shaped oligomerization of the peptide subunits, (b) the presence of tandemly arrayed CRDs along the peptide subunits, or (c) both subunit oligomerization and tandemly arrayed CRDs, such as in the recently identified F-type lectin family. This lectin family, that received its 


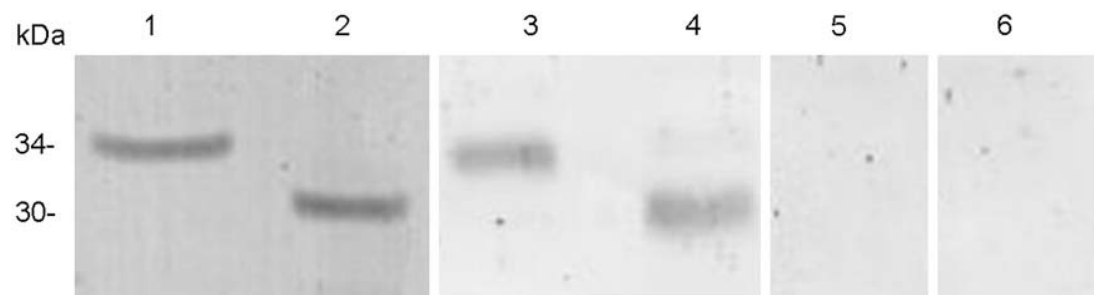

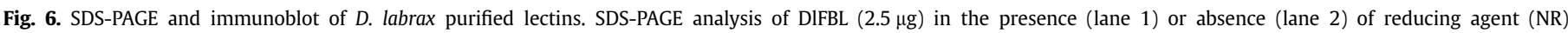

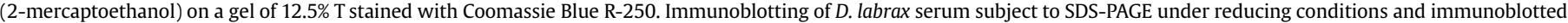

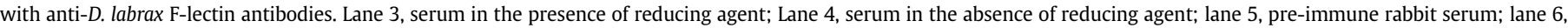
antiserum absorbed with DIFBL fraction .

name for the nominal specificity for fucose of the first members identified, is characterized by the highest multiplicity of tandemly arrayed CRDs observed in any lectin peptide subunit described so far [11].

In a previous report [24], we characterized a $34 \mathrm{kDa}$ fucosebinding lectin from $D$. labrax serum (DIFBL) isolated through Sepharose CL6B affinity chromatography. In a subsequent study [23] we established that DIFBL and SauFBL, a lectin from the gilt head sea bream (S. aurata) of similar binding properties, were both members of the F-type lectin family as concluded from N-terminal amino acid sequence comparison. In the present study we further purified the $34 \mathrm{kDa}$ lectin by a two-step chromatography procedure in which the pooled active fractions from a Sepharose CL6B column were loaded onto a L-fucose-agarose column. The second chromatography step enabled the separation of the $34 \mathrm{kDa}$ protein from a $70 \mathrm{kDa}$ component that co-eluted in the Sepaharose 6B CL separation step [24]. In the present paper we show that the $70 \mathrm{kDa}$ $\mathrm{N}$-terminal sequence is identical to fish transferrin $\mathrm{N}$-terminal amino acids (1-7 amino acids; Accession number: AY365052.1).

The complete DIFBL cDNA sequence revealed that this lectin, like the $M$. saxatilis F-lectins, possesses two tandemly arrayed CRDs. Odom and Vasta [11] isolated from serum and liver of the striped bass (M. saxatilis) two fucose-binding lectins of 30 and $32 \mathrm{kDa}$ (MsaFBP32 and MsaFBP32II), each carrying two tandem CRDs that exhibit the F-type carbohydrate-recognition motif and the typical F-type structural fold established for the A. anguilla F-type lectin [12]. There are relevant biochemical and structural similarities between DIFBL and the two binary tandem CRD F-type lectins isolated from striped bass [11].

The DIFBL cDNA sequence consists of an open reading frame encoding 312 amino acid residues including 18-residue signal sequence at the $\mathrm{N}$-terminal. The deduced size of $34 \mathrm{kDa}$ for the mature protein is in agreement with subunit size of the lectin previously isolated from the serum through Sepharose CL6B column affinity chromatography [24]. The deduced amino acid sequence differed at the first position from the previously reported [24]. $\mathrm{N}$-terminal sequence of the isolated $34 \mathrm{kDa}$ lectin. With respect to that, a protein sequencing mistake at the first residue could be occurred.

Comparative sequence analysis revealed that DIFBL is a binary tandem domain F-type lectin with the $\mathrm{N}$ - and C-CRDs connected by a nine amino acid peptide linker. BLAST analysis disclosed sequence homologies with vertebrate F-lectin CRDs. In the phylogenetic tree, DIFBL is included in a cluster of teleost binary F-type lectins, clearly distinguishable from those F-lectins with a single CRD or containing more than two CRDs. Both N-CRD and C-CRD showed highly conserved sequences characterized by Cys residues located at sequence positions consistent with the formation of two intrachain disulphide bonds. The presence of intrachain disulphide bonds was supported by the different electrophoretic mobilities of DIFBL under reducing $(34 \mathrm{kDa})$ and non-reducing conditions (30 kDa). Binary CRD F-type lectins are present in several teleost species, and are most likely the result of gene duplications that took place independently in various perciform lineages [11]. In contrast with the single CRD F-lectins from eels, which may represent the ancestral state of this lectin family within the rayfinned fish, the binary homologues may have diversified in the teleosts through gene duplications and speciation events, such as the four-tandem CRD F-lectins that are unique to the salmoniformes [11]. Although no studies were carried out so far concerning the potential oligomerization of the DIFBL $34 \mathrm{kDa}$ peptide subunits, the formation of trimers, such as demonstrated in the A. anguilla F-lectin [12] or as proposed for the $M$. saxatilis lectins cannot be ruled out.

To examine the tissue localization of DIFBL, antibodies against the protein were raised, and their specificity validated by complete absorption of the antiserum activity with the purified DIFBL. Western blot analysis of crude serum and tissue extracts (liver, intestine, head kidney, spleen, ovary, gill, and heart), assayed with the specific antibodies only identified a $34 \mathrm{kDa}$ band corresponding to the expected mobility of DIFBL. Differences in band intensities suggest that the lectin is mainly expressed in liver tissue, and to a lesser extent in intestine and head kidney, being very scarce in the gill, heart, spleen and ovary. These results are in accordance with the RT-PCR experiments, which revealed the highest transcript levels in liver, followed in decreasing order by intestine, head kidney, spleen, ovary, and transcripts absent in gill and heart. The liver appears to be the main site of DIFBL expression, and, consistently with observations on other F-lectins $(11,13)$, it can also be expressed at lower levels in intestine, head kidney, spleen and ovary. To identify the liver and intestine cells which express DIFBL, in situ hybridization and immunohistochemistry analyses were

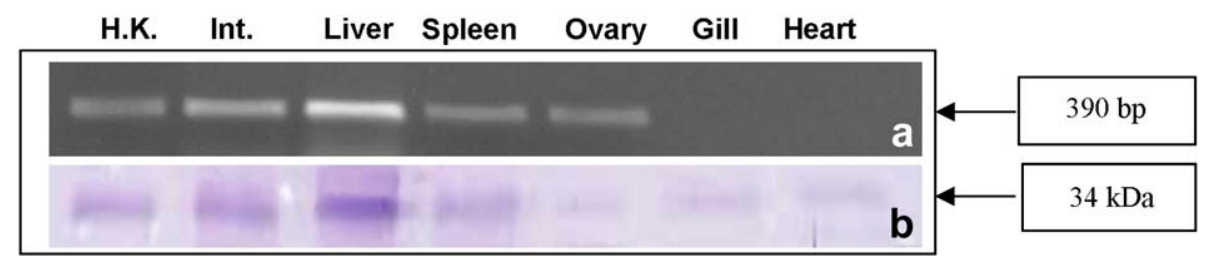

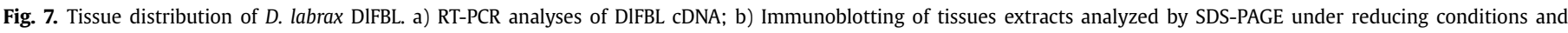
immunoblotted with anti-DIFBL antibodies. H.K. = Head Kidney; Int. = intestine. 

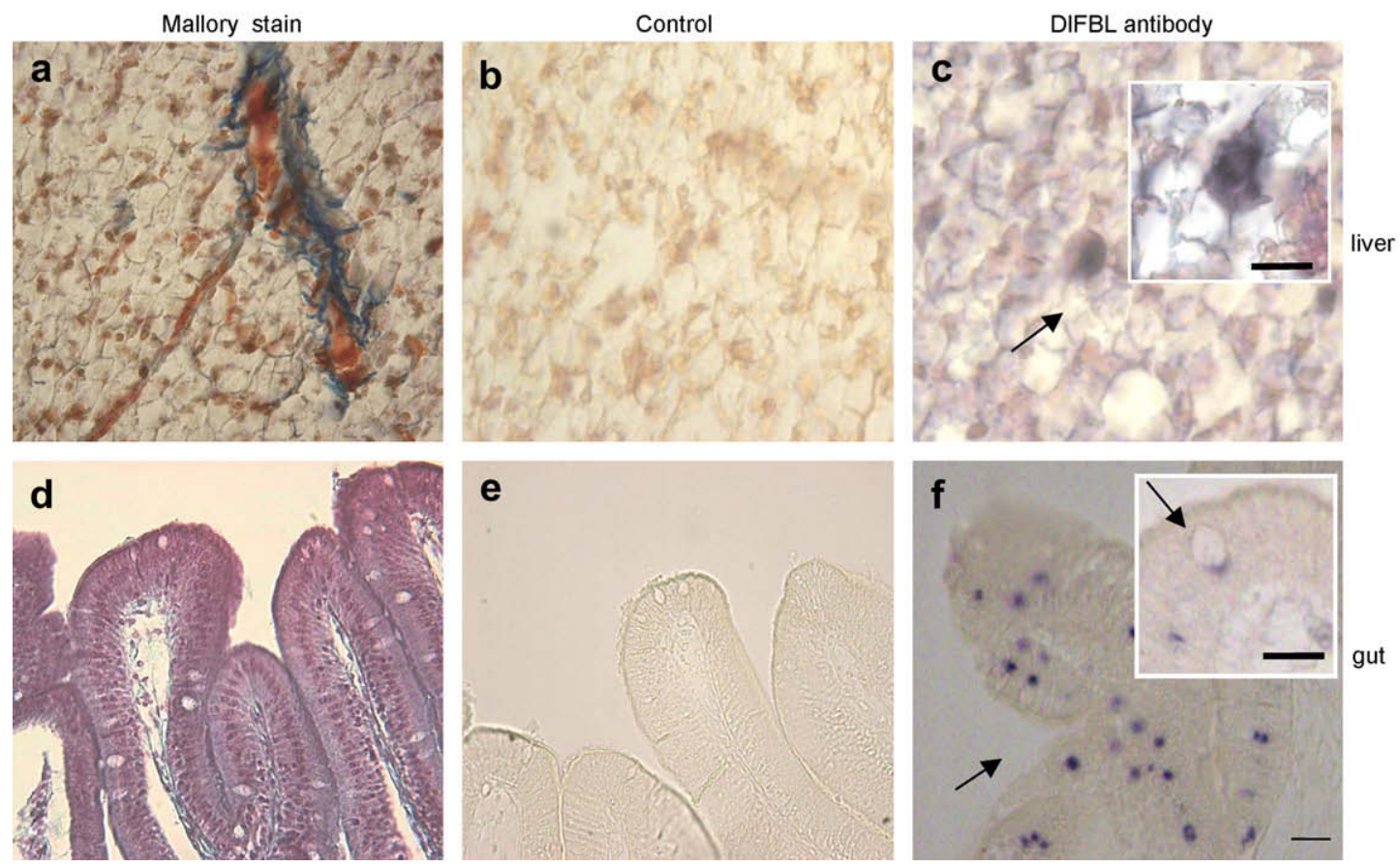

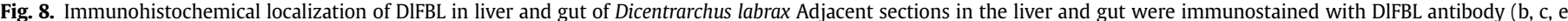

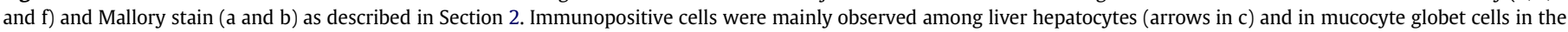
gut sections. No immunoreactivity was observed with DIFBL antibody preabsorbed with DIFBL (b and e). Bars: a-f, $20 \mu \mathrm{m}$; c, f spots $10 \mu \mathrm{m}$.
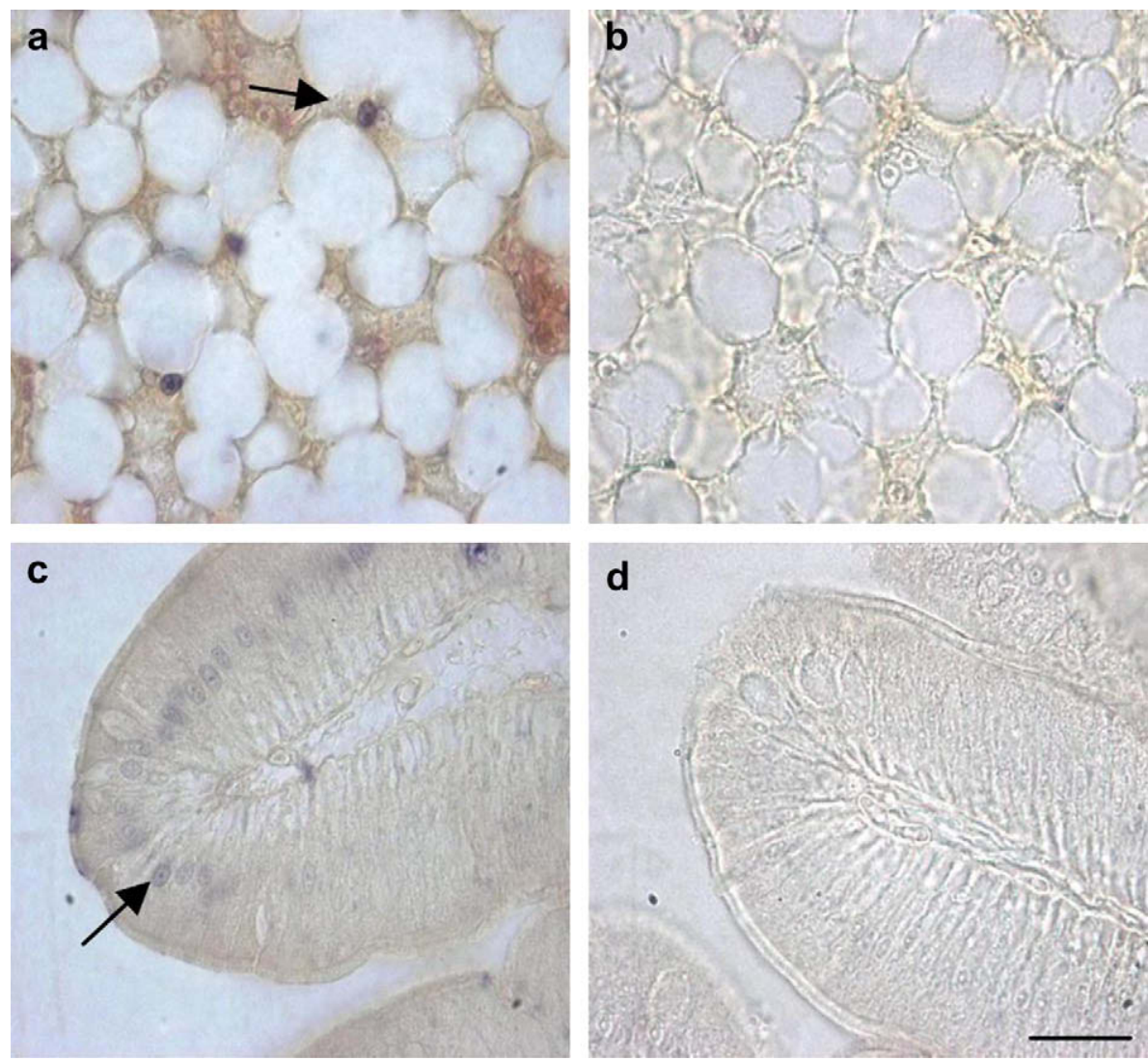

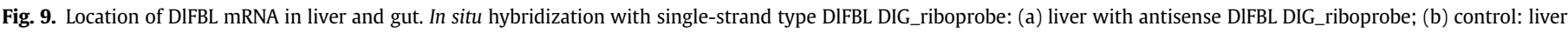
with sense DIFBL DIG_riboprobe; (c) intestine with antisense DIFBL DIG_riboprobe; (d) control: intestine with sense DIFBL DIG_riboprobe; (a and b): bar $5 \mu \mathrm{m}$; (c and d): $10 \mu \mathrm{m}$. 

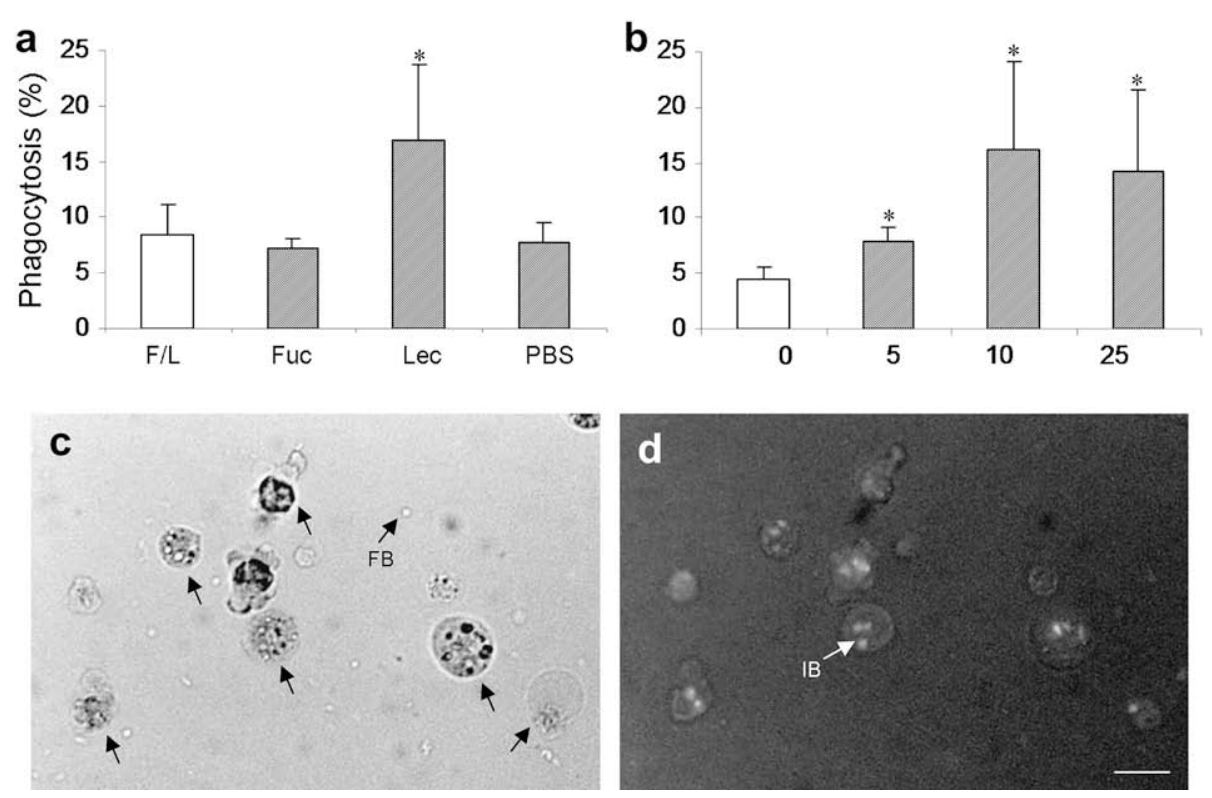

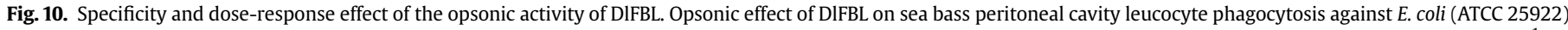

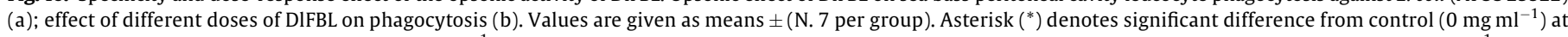

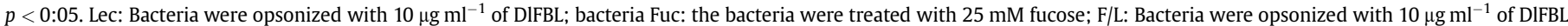

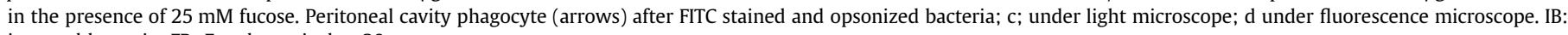
ingested bacteria; FB: Free bacteria. bar $20 \mu \mathrm{m}$.

carried out. In agreement with the expression of fucose-binding lectins from A. anguilla [13], M. saxatilis and Oncorhynchus mykiss F-lectin [11,22], DIFBL transcripts were located in the nucleus of liver parenchymal cells and intestinal mucocytes of the columnar epithelium, whereas immunohistochemical analysis revealed that the DIFBL protein was located in the cytoplasm. Preliminary immunoblot results (work in progress) indicated that the DIFBL expression may be enhanced by challenging fish with intraperitoneal injection of bacteria (Vibrio alginolyticus).

The F-type lectin family received its name from the preferred binding to L-fucose of most of the members characterized so far $[11,12]$. The monosaccharide $\mathrm{L}$-fucose is present as a non-reducing terminal sugar of a large variety of pro- and eukaryotic glycans [35]. It has been recently proposed that free L-fucose can be released into the human intestinal lumen through the hydrolytic activity of members of the indigenous microbial flora, as well as potential microbial pathogens, [36]. It is noteworthy that the presence of free L-fucose upregulated gene expression and secretion of their encoded proteins that are involved in both the innate and adaptive immune responses in which an active role of a fucose-binding lectin cannot be excluded [36]. In this regard, L-fucose-specific opsonizing capacity of DIFBL for bacteria targeted for phagocytosis by peritoneal macrophages suggests that this F-lectin may mediate immune defence responses both in the intestinal mucus and the blood stream.

\section{Acknowledgements}

We thank Dr. Eric Odom for generously providing the M. saxatilis FBL primers, and Prof. Nicolò Parrinello for helpful reading of the manuscript. We are also grateful to Mrs G. Miceli and Mario Guarcello (Department of Animal Biology, University of Palermo) for expert fish maintenance. This work was supported by grants from MIUR and University of Palermo (Research and CORI grants to N.P. and M.C.). Work at the Center of Marine Biotechnology, UMBI, was supported by grants MCB-00-77928 from the National Science Foundation and RO1 GM070589-01 from the National Institutes of Health to G.R.V.

\section{References}

[1] Drickamer K. C-type lectin-like domains. Curr Opin Struct Biol 1999;9:585-90.

[2] Kuhlman M, Joiner K, Ezekowitz AB. The human mannose-binding protein functions as an opsonin. J Exp Med 1989;169:1733-45.

[3] Cooper D, Butcher CM, Berndt MC, Vadas MA. P-selectin interacts with a beta 2-integrin to enhance phagocytosis. J Immunol 1994;153:3199-209.

[4] Tino MJ, Wright JR. Surfactant protein A stimulates phagocytosis of specific pulmonary pathogens by alveolar macrophages. Am J Physiol 1996; 270:677.

[5] Matsushita M, Endo Y, Taira S, Sato Y, Fujita T, Ichikawa N, et al. A novel human serum lectin with collagen- and fibrinogen like domains that functions as an opsonin. J Biol Chem 1996;271:2448-54.

[6] Arason GJ. Lectins as defence in vertebrates and invertebrates. Fish Shellfish Immunol 1996;6:277-89.

[7] Drickamer K, Dodd RB. C-type lectin-like domains in Caenorhabditis elegans: predictions from the complete genome sequence. Glycobiology 1999;9: 1357-69.

[8] Russel S, Lumsden JS. Function and heterogeneity of fish lectins. Vet Immunol Immunopathol 2005;108:111-20.

[9] Vasta GR, Ahmed H, Odom EW. Structural and functional diversity of lectin repertoires in invertebrates, protochordates and ectothermic vertebrates. Curr Opin Struct Biol 2004;11:53-62.

[10] Odom EW. F-type lectins: biochemical, genetic, and topological characterization of a novel lectin family in lower vertebrates [PhD Thesis]. College Park: University of Maryland; 2004.

[11] Odom E, Vasta GR. Characterization of a binary tandem domain F-type lectin from striped bass (Morone saxatilis). J Biol Chem 2006;281:1698-713.

[12] Bianchet MA, Odom EW, Vasta GR, Amzel LM. A novel fucose recognition fold involved in innate immunity. Nat Struct Biol 2002;9:628-34.

[13] Honda S, Kashiwagi M, Miyamoto K, Takei Y, Hirose S. Multiplicity, structures, and endocrine and exocrine natures of eel fucose-binding lectins. J Biol Chem 2000;275:33151-7.

[14] Tateno H, Saneyoshi A, Ogawa T, Muramoto K, Kamiya H, Saneyoshi M. Isolation and characterization of rhamnose-binding lectins from eggs of steelhead trout (Oncorhynchus mykiss) homologous to low density lipoprotein receptor superfamily. J Biol Chem 1998;273:19190-7.

[15] Suzuki Y, Tasumi S, Tsutsui S, Okamoto M, Suetake H. Molecular diversity of skin mucus lectins in fish. Comp Biochem Physiol 2003;136:723-30.

[16] Jimbo M, Usui R, Sakai R, Muramoto KH. Purification, cloning and characterization of egg lectins from the teleost Tribolodon brandti. Comp Biochem Physiol B Biochem Mol Biol 2007;1:17331-772.

[17] Arason GJ, Guðdmunsdottir S, Elgaard L, Thiel S, Jensenius J. An opsonin with mannan binding protein (MBP)-like activity in the Atlantic salmon, Salmo salar. Scand J Immunol 1994;40:692.

[18] Yano T. The non-specific immune system: humoral defence. In: Iwama G, editor. The fish immune system: organism, pathogen, and environment. San Diego; 1996, p. 105-156. 
[19] Jensen LE. Acute phase response in salmonids: evolutionary analyses and acute phase response. J Immunol 1997;158:384-92.

[20] Listinsky J, Siegal P, Listinsky M. A potentially critical molecule in pathologic processes including neoplasia. Am J Clin Pathol 1998;110:425-40.

[21] Ottinger CA, Johnson SC, Ewart KV, Brown LL, Ross NW. Enhancement of antiAeromonas salmonicida activity in Atlantic salmon (Salmo salar) macrophages by a mannosebinding lectin. Comp Biochem Physiol 1999;123:53-9.

[22] Tateno H, Ogawa T, Muramoto K, Kamiya H, Saneyoshi M. Rhamnose-binding lectins from eggs from steelhead trout (Oncorhynchus mykiss) Eggs recognize bacterial lipopolysaccharides and lipoteichoic acid. Biosci Biotechnol Biochem 2002;66:604-12.

[23] Cammarata M, Benenati G, Odom E, Salerno G, Vizzini A, Vasta GR, et al Isolation and characterization of a fish F-type lectin from gilt head bream (Sparus aurata) serum. Biochim Biophis Acta 2007;1770:150-5.

[24] Cammarata M, Vazzana M, Chinnici C, Parrinello N. A serum fucolectin isolated and characterized from sea bass Dicentrarchus labrax. Biochim Biophis Acta 2001;1528:196-202.

[25] Bradford MM. A rapid and sensitive method for the quantitation of microgram quantities of protein utilizing the principle of protein-dye binding. Ana Biochem 1976;72:248-54.

[26] Laemmli UK. Cleavage of structural proteins during the assembly of the head of bacteriophage T4. Nature 1970;227:680-5.
[27] Thompson JD, Higgins DG, Gibson TJ. CLUSTAL W: improving the sensitivity of progressive multiple sequence alignment through sequence weighting, position-specific gap penalties and weight matrix choice. Nucleic Acids Res 1994;22:4673-80.

[28] Thompson JD, Gibson TJ, Plewniak F, Jeanmougin F, Higgins DG. The CLUSTAL X windows interface: flexible strategies for multiple sequence alignment aided by quality analysis tools. Nucleic Acids Res 1997;25:4876-82.

[29] Alonso MC, Cano I, Castro D, Perez-Prieto SI, Borrego JJ. Development of an in situ hybridisation procedure for the detection of sole aquabirnavirus in infected fish cell cultures. J Virol Methods 2004;116:133-8.

[30] Mallory FB. Pathological technique. Philadelphia: W.B. Saunders Co.; 1938. p. 73.

[31] Gomori G. A rapid one-step trichrome stain. Am J Clin Pathol 1950;20:661-4.

[32] Hed J. Methods for distinguishing ingested from adhering particles. Methods Enzymol 1986;132:198-204.

[33] Goldstein IJ, Huges RC, Monsigny M, Osawa T, Sharon N. What should be called a lectin? Nature 1980;285:66.

[34] Rabinovich GA, Toscano MA, Jackson SS, Vasta GR. Functions of cell surface galectin-glycoprotein lattices. Curr Opin Struct Biol 2007;17:513-20.

[35] Staudacher E, Altmann F, Wilson IB, Marz L. Fucose in N-glycans: from plant to man. Biochim Biophys Acta 1999;1473:216-36.

[36] Chow W, Lee Y. Free fucose is a danger signal to human intestinal epithelial cells. Br J Nutr 2008;99:449-54. 